\title{
Announcements
}

\section{Haematological Cytochemistry}

Organised by the Histochemistry and Cytochemistry Section of the Royal Microscopical Society at Jesus College, Cambridge, September 27-29, 1983. The meeting will bring together the disciplines of haematology, immunology, histopathology and cytochemistry and will discuss the contribution of new methodologies to the study of normal and neoplastic haemopoietic cells. Presentations will be given in 4 half-day sessions under the following headings: (1) cytochemistry of haemopoietic cells; (2) cytochemistry of lymphoid cells; (3) immunocytochemistry, and (4) ultrastructural cytochemistry. Each session will have an invited Keynote Speaker followed by free communications. Papers on these and other aspects of haematological cytochemistry are welcome. Invited speakers include Prof. D. Bainton (Calif.), Prof. F.G.J. Hayhoe (Cambridge), Prof. G. Janossy (London) and Dr. A.D. Crockard (Belfast). Meeting organiser: Dr. D. Catovsky, Royal Postgraduatge Medical School, Hammersmith Hospital, Ducane Road, London, W. 12. For further information, applications and abstract form write to the Administration, Royal Microscopical Society, 37/38 St. Clements, Oxford 0X4, 1AJ (England).

The American Red Cross 15th Annual Scientific Symposium The American Red Cross 15th Annual Scientific Symposium entitled 'Advances in Immunobiology: Blood Cell Antigens and Bone Marrow Transplantation’ will be held May 4-6, 1983, in Washington, D. C.

The symposium will address cell surface antigens of platelets, granulocytes, monocytes and lymphocytes, together with an update on bone marrow transplantation.

Pre-registration required. For information, please contact: Symposium Coordinator, American Red Cross Blood Services Laboratories, 9312 Old Georgetown Road, Bethesda, MD 20814. Tel. (301)530-6040. 